\title{
Cyclical climate oscillation alters species statistical relationships with local habitat
}

\author{
Sarah M. Roberts ${ }^{1, *}$, Andre M. Boustany ${ }^{2}$, Patrick N. Halpin ${ }^{1}$, Ryan R. Rykaczewski ${ }^{3}$ \\ ${ }^{1}$ Marine Geospatial Ecology Lab, Nicholas School of the Environment and Earth Sciences, Duke University, Durham, \\ NC 27708, USA \\ ${ }^{2}$ Monterey Bay Aquarium, 886 Cannery Row, Monterey, CA 93940, USA \\ ${ }^{3}$ Marine Science Program, University of South Carolina, Columbia, SC 29208, USA
}

\begin{abstract}
As anthropogenic climate change increases the temperatures of the world's oceans, the survival rates, spatial distributions, and phenology of marine species are affected. Additionally, cyclical climate oscillations, such as the North Atlantic Oscillation (NAO), influence species presences throughout the Atlantic Basin. We evaluate the potential effects of local habitat variability on the nearshore presence of 7 commercial fish species along the South Atlantic Bight. Employing random forest models, we assess the relationships between historical observed presence and bottom temperature (BT), salinity, benthic habitat structure, and the NAO. Our results suggest that for some species, the influence of BT on species nearshore presence depends on the phase of the NAO. Thus, the statistical responses of some species to changing ocean temperatures will largely depend on the phase of the NAO.
\end{abstract}

KEY WORDS: Climate change · Climate variation · North Atlantic Oscillation · Species distribution $\cdot$ Species-environment relationships

\section{INTRODUCTION}

Over the last several decades, anthropogenic greenhouse gas emissions have driven considerable increases in global and regional ocean temperatures and salinity contrasts (Levitus et al. 2012). As ocean temperatures warm and salinity contrasts amplify, the geographic ranges of marine species have shifted and will likely continue to shift as climate change persists (Perry et al. 2005, Nye et al. 2009, Sumaila et al. 2011, Pinsky et al. 2013). In addition to species reacting to anthropogenic warming, cyclical climate oscillations affecting ocean conditions have been shown to influence marine species ranges (Nye et al. 2009). Considering the impacts of these natural climate oscillations as well as anthropogenic warming allows for more comprehensive understanding of the ecological processes that influence species distributions. Here, we demonstrate that the historical empir-

\footnotetext{
*Corresponding author: sarah.m.roberts@duke.edu
}

ical relationship between certain species presences and local bottom temperatures (BTs) is influenced by the phase of a cyclical climate oscillation, the North Atlantic Oscillation (NAO), which influences temperatures as well as precipitation, wind stress, and currents in the region.

Although most previous research along United States coastal waters has focused on shifts in northern species in areas such as the gulfs of Maine and Alaska (Pörtner et al. 2010, Moerlein \& Carothers 2012), the unique oceanographic conditions and economic importance of fisheries in the South Atlantic Bight (SAB) necessitate similar research in these southern regions. Cape Hatteras, North Carolina, represents a biogeographic boundary, where the meeting of the warmer Gulf Stream and the colder Labrador Shelf water from the northern Labrador Current (Talley \& McCartney 1982) leads to increased levels of productivity (Aller et al. 2002) and

() The authors 2019. Open Access under Creative Commons by Attribution Licence. Use, distribution and reproduction are unrestricted. Authors and original publication must be credited. 
diversity (Byrd et al. 2014). Accordingly, this area represents the northern and southern boundary for many species ranges (Briggs \& Bowen 2012) and promotes productive commercial and recreational fisheries (Steve et al. 2001). Recent work by Morley et al. (2018) predicted shifts in the thermal habitat for species in the $\mathrm{SAB}$, concluding that species will shift towards the Mid-Atlantic. Morley et al.'s (2018) models failed to include cyclical climate oscillations and instead predict shifts in species thermal habitat based on associations with ocean temperature and seafloor rugosity. Here, we argue that shifts in the relationship between species presence and local environment are influenced by the NAO phase. Thus, understanding the environmental drivers of historic probability of presence of commercial species along the South Atlantic and Mid-Atlantic bights in relation to temperature as well as salinity, benthic habitat structure, and the NAO could have significant management implications.

The NAO is a pressure and circulation pattern, which is a measurement of the sea surface pressure differences between the subtropical high and subpolar low. A positive NAO phase is associated with warmer temperatures in the eastern United States, with the opposite pattern occurring in negative phases (Hurrell 1995). Research has demonstrated that the NAO influences ecosystem processes throughout the Atlantic Basin, and several studies have observed the importance of the NAO for predicting northern species abundances and ecosystemwide shifts (Stige et al. 2006, Nye et al. 2009). In the $\mathrm{SAB}$, the NAO influences temperatures, precipitation, transport of the North Atlantic Current, and the strength of the gyre circulation (Hurrel \& Dickenson 2004) (Fig. 1). During a positive phase of the NAO, warm, more saline water advances further northeastward and blocks the cooler, less saline Labrador Subarctic Shelf water from the north. Temperature fluctuations associated with the NAO have been shown to influence the recruitment of several fish stocks (Santiago 1998), and climate oscillations have been shown to influence species recruitment through changes in ocean currents (Myers \& Drinkwater 1989). Cod and salmon recruitment and distributions have been affected by variations in shelf water dynamics resulting from NAO conditions (Drinkwater et al. 2003). Research has indicated that most variance in the NAO occurs in the winter months, so the winter NAO (WNAO) was also used for analysis (Nye et al. 2009, Hurrell et al. 2013). The strong NAO in the winter is associated with a strengthening of the jet stream, which is driven by an equator-pole tem-

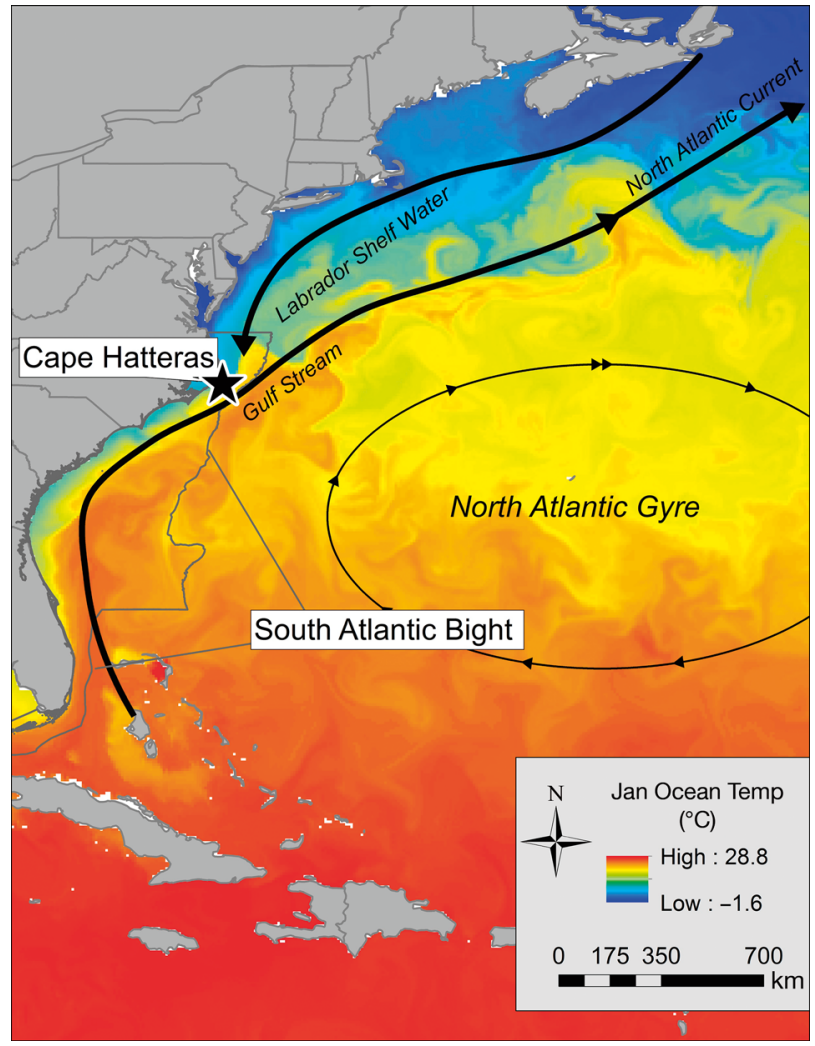

Fig. 1. Oceanography of the North Atlantic, including the Gulf Stream, which flows to the North Atlantic Current, Labrador Shelf water (resulting from the Labrador Current to the north), the North Atlantic Gyre, the South Atlantic Bight, and location of Cape Hatteras, NC (black star). Background raster is a HYbrid Coordinate Ocean Model climato-

logy dataset for January 2010 ocean temperatures

perature gradient which tends to strengthen in the winter (due to less seasonal cooling in the tropics than the poles) (Hanna \& Cropper 2017). During positive WNAO phases, the jet stream flows from west to east, keeping colder air further north and resulting in warmer winters in the United States and Europe. The opposite pattern occurs during a negative phase of the WNAO (Ottersen et al. 2001). Given the influence of the NAO on species dynamics, we examine the interactive effects of the NAO and local BTs and salinity on historical species presence to understand the understudied ecological processes influenced by the NAO that may affect species distributions.

Understanding the historic shifts in probability of presence of commercial species and how these relate to changing environmental conditions and cyclical oscillations could have significant management implications, especially in an understudied area such as the SAB. Identifying which species are more influenced by cyclical oscillations compared to chang- 
ing ocean temperatures will highlight specific fisheries that may need more ecologically sound species distribution models. Considering the commercial importance of these species, understanding which environmental processes inform their presence and distribution is essential, especially under expected ocean warming. Additionally, we argue that for species that are more influenced by the NAO, it may be harder to predict future distributions under climate change, as the predictability of the NAO is debatable (Rind et al. 2005). Contrastingly, species that are more influenced by local BTs and salinities may show linear shifts in distributions going forward. As species shift out of traditional areas, fishers may be faced with lost access to stocks, and managing bodies may have to re-examine existing static management strategies. In the case of the Pacific salmon fishery, a lack of understanding of climate-related influences on stock abundance and migrations led to a breakdown of a cooperative harvesting agreement between the United States and Canada (Miller \& Munro 2004). In Alaska, the North Pacific Fishery Management Council has taken a risk-averse approach to managing their fisheries under a changing climate by closing the Arctic to commercial fishing and developing adaptive management strategies for areas where research has identified the linkage between climate change and shifting fisheries distributions (Stram \& Evans 2009). In the Mid-Atlantic, plans for
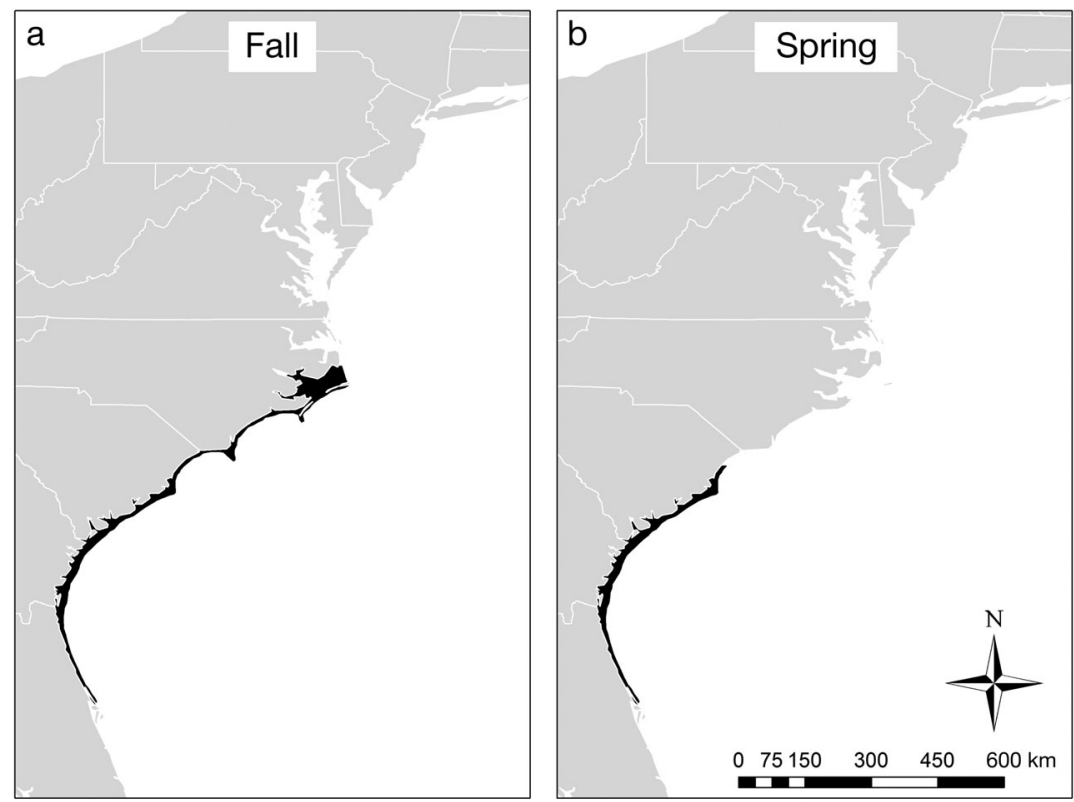

Fig. 2. Extent of the original Southeast Area Monitoring and Assessment Program trawl surveys (black) in the (a) fall and (b) spring. Fishery-independent surveys were conducted between 1990 and 2014 in inshore strata (4.6-9.1 m depth) using a stratified random sampling technique an ecosystem-based management approach have documented the necessity of including climate change impacts on species and ecosystem distributions, and these efforts are in their preliminary stages (MAFMC 2016). Considering the precautionary lessons in the Pacific salmon fishery and the recent call for adaptive fisheries management under climate change, this paper presents a relevant and necessary study on the relative role of the NAO on species presences along the SAB.

\section{MATERIALS AND METHODS}

\subsection{Species presence data}

Species presence data were obtained from the Southeast Area Monitoring and Assessment Program-South Atlantic (SEAMAP-SA) bottom trawl survey dataset (SEAMAP-SA Data Management Work Group 2016). Fishery-independent surveys were conducted between 1990 and 2014 in inshore strata (4.6-9.1 m depth) and offshore strata (4-10 m depth) from Cape Hatteras, North Carolina, to Cape Canaveral, Florida, in the spring (April, May) and fall (September, October, November) of each year (Fig. 2) using a stratified random sampling method. We only included tows that were collected in inshore strata, as those were consistently sampled throughout the study period (Morley et al. 2017). In total, 102035 inshore tows were conducted in the spring and 114982 inshore tows in the fall, all of which were included in our analysis. Species count data were recorded for 260 species, and presence-absence data were derived for this analysis. Collections were made at randomly selected sites in 24 predefined inshore strata. For this study, 7 commercially targeted species that occurred in at least 500 tows were selected for modeling (SEAMAP-SA Data Management Work Group 2014).

Atlantic croaker, Atlantic menhaden, Atlantic spadefish, butterfish, spot, summer flounder, and weakfish were selected for this analysis. Each of these species is commercially caught in the South Atlantic and Mid-Atlantic bights; thus, their responses to changing 
ocean conditions are of importance to management. Additionally, these species were selected because they represent a broad range of pelagic as well as benthic species. Atlantic croaker, Atlantic spadefish, spot, and weakfish are considered demersal consumers (or bottom-dwelling species). Butterfish and Atlantic menhaden are considered pelagic schooling species, whereas summer flounder is a benthic species (living on the sea floor). Atlantic croaker are found between the Chesapeake Bay and northern Florida, and they spawn in warm pelagic waters in the fall and winter, with larvae settling in estuarine and riverine habitats (ASMFC 1987). Atlantic menhaden are found from northern Florida to Nova Scotia, and they migrate south during the fall and winter to spawn around North Carolina (Rogers \& Van Den Avyle 1983a). Spot are found mainly between South Carolina and the Chesapeake Bay. They migrate to bays and estuaries in the spring and summer and move offshore to spawn in the fall (Phillips et al. 1989). Summer flounder are found between Florida and Nova Scotia, and they move offshore in the fall to spawn, with juveniles predominantly residing in inshore areas (Rogers \& Van Den Avyle 1983b). Weakfish occur between Florida and Nova Scotia and migrate inshore and northward during the spring and summer to spawn (Mercer 1989). Butterfish occur between Florida and Nova Scotia and migrate offshore in late fall (Adams et al. 2015). Atlantic spadefish are found from Brazil to Massachusetts and occur inshore during the summer to spawn and move offshore in the winter (Hayse 1987).

\subsection{Study area}

The SAB refers to the continental shelf between Cape Canaveral, Florida, and the North CarolinaVirginia border (Fig. 1). The SAB continental shelf extends between 40 and $140 \mathrm{~km}$, with the shelf bottom comprised of rock reefs $(20 \%)$ as well as sand, mud, and gravel substrates (Miller \& Richards 1980). Given the large prevalence of reef habitat, the SAB supports a large number of reef fish fisheries. Fisheries in the SAB are managed by NOAA's South Atlantic Branch and the South Atlantic Fishery Management Council. Key commercial fisheries include blue crab, clams, flounders, groupers, king mackerels, oysters, shrimp, snappers, swordfish, and tunas, and key recreational fisheries include Atlantic croaker, spot, black sea bass, bluefish, dolphinfish, king mackerel, sharks, sheepshead porgy, red drum, Spanish mackerel, and spotted seatrout (NOAA
2015). The SAB has a higher prevalence of tropical species and habitats, a result of the influence of the Gulf Stream bringing warmer waters from the south to the area (Fig. 1). The Gulf Stream flows at 4 to 5 knots along the SAB shelf break before it deflects to the ocean at Cape Hatteras (Stommel 1958).

\subsection{Environmental data}

We selected covariates that have been shown to influence fish species presence (Nye et al. 2009). For each trawl, bottom salinity, BT, benthic habitat structure, NAO, and WNAO were extracted from online datasets at the trawl location as predictor variables. BT, and salinity are key predictors for species presence, and have important implications for climate change research (Hurst \& Conover 2002). BT and salinity were obtained using the MGET toolbox for ArcGIS 10.1 (Roberts et al. 2010); both were downloaded for the specific trawl date and location from the data-assimilative HYbrid Coordinate Ocean Model (HYCOM) dataset using a $1 \mathrm{~d}$ time step. HYCOM is an oceanographic model that produces 32 vertical layers including ocean temperature, salinity, sea surface height, and wind stress as well as other 3- and 4dimensional variables. The system uses the Navy Coupled Ocean Data Assimilation (NCODA) system (Cummings 2005) for data assimilation. NCODA uses the model forecast as a first guess in a multivariate optimal interpolation (MVOI) scheme and assimilates available satellite altimeter observations (along track obtained via the Naval Oceanographic Office Altimeter Data Fusion Center satellite) and in situ sea surface temperature as well as available in situ vertical temperature and salinity profiles from expendable bathythermographs, Argo floats, and moored buoys (Fox et al. 2002). Seven HYCOM models (HYCOM NCODA Global 1/12 ${ }^{\circ}$ Reanalysis GLBu0.08 Expts 19.0, 19.1, 90.9, 91.0, 91.1, 91.2) were temporally concatenated to create a continuous dataset of BT and salinity, ranging from 1992 to 2017. These model runs differed slightly in their configurations (time steps, advection scheme, mixing, vertical structure, slight change in NCODA, and MVOI transition to 3-dimensional analysis in 2013), but the differences are not expected to influence the applicability of the output (Chassignet et al. 2007). Oceanographic model data were used as these report bottom variables (BT and salinity), which should be a better measure of the environment experienced by the fish species examined in this study compared to the in situ surface temperature and salinity. Studies have 
shown that the HYCOM model is a good approximation of the in situ measured environment (Chassignet et al. 2007) (see Fig. S1 in the Supplement at www. int-res.com/articles/suppl/m614p159_supp.pdf).

Winter and yearly NAO (Hurrell 1995) indices were added to the dataset based on the year collected. The WNAO and NAO are measured as the difference in normalized sea level pressure between Lisbon, Portugal, and Reykjavik, Iceland. We calculated the co-correlation of each covariate and determined that no 2 variables were highly correlated (Kendall's correlation $<0.65$, see Fig. S2). We ran each model with a 1 yr lagged NAO value to test these relationships. For the final models presented here, non-lagged values were used, as these performed similarly in terms of variable importance in the random forest models.

\subsection{Benthic habitat structure}

The benthic habitat structure variable was created by combining bathymetric and substrate data and using methods adopted from The Nature Conservancy's (TNC's) North Atlantic Bight Marine Assessment (NAMERA) (Greene et al. 2010). The General Bathymetric Chart of the Oceans (GEBCO) 201430 arc-second grid was downloaded for the study area (GEBCO 2014). From the GEBCO bathymetric dataset, 2 aspects of seafloor structure (topographic seabed form and substrate) were combined to create a benthic habitat structure raster for the entire study area, similar to the Ecological Marine Units variable from TNC's study.

Seabed topographic form was calculated by combining slope class and position classes acquired from the bathymetric dataset for each cell. Seabed position was determined by the elevation differences between any given cell and the mean of the surrounding cells within a 100 cell radius (Fels \& Zobel 1995, Greene et al. 2010). Position was then grouped into 3 classes, as determined by TNC's NAMERA (see Table S1 and Fig. S3). Because any cell with a relative position of 0 could indicate either a side slope or a flat area, slope is needed to differentiate between these features. Slope was calculated using the ArcGIS slope tool and reclassified according to TNC's thresholds (see Table S2 and Fig. S3). Slope and relative position were combined to create 7 categories of seabed topographic form as determined by TNC (depression, low slope, steep, mid flat, side slope, high flat, and high slope) (see Table S3 and Fig. S3). Finally, the substrate variable was obtained from both TNC's SAB Marine Assessment (TNC 2015) and NAMERA. The substrate variables for the 2 studies were aggregated into 1 raster dataset and reclassified into the following categories according to TNC's NAMERA: hardbottom, reef, Oculina bank, mud, sand, and gravel.

Both variables were coded using the zip code approach, where substrate was given a unique value in the 1000 s place, and seabed topographic form was given a unique value in the 100 s place. Thus, when all of the variables were combined, each code represented a unique combination of substrate and seabed topographic form (see Fig. S2). The final benthic habitat structure dataset was paired to the species presence dataset.

\subsection{Random forest analysis}

Random forest analyses were used to determine the relationship between species presence and salinity, BT, and habitat type as well as the climate indices (NAO, WNAO). Random forests, a machine-learning algorithm similar to classification and regression trees (Brieman 1984), have been extensively utilized by ecologists because of their high accuracy with classification studies, ability to depict interactions between categorical and continuous variables, and greater interpretability compared to methods such as neural networks (Cutler et al. 2007).

For each species, a random forest analysis was conducted using the party package (Hothorn et al. 2006) for R statistical software (version 3.4.1) (R Development Core Team 2004). Each trawl in the training data set was given a value of 1 where the species of interest was present and a value of 0 where the species of interest was absent. Separate random forest models were produced for the spring and fall seasons. We used the Boruta algorithm in R (Kursa 2014) for variable selection which compares the importance of real predictor variables with those of random shadow variables for multiple runs of the random forest (Degenhardt et al. 2017). For each species, all variables were considered important using the Boruta method except for benthic habitat structure for summer flounder in the spring. We initially ran all models with presence-absence as well as abundance and determined that the presence-absence models performed better in terms of $\mathrm{R}^{2}$ values for 11 of 14 cases (see Table S4). Model performance was measured by the mean error of observed vs. predicted results, the variance explained, and sensitivity vs. specificity of predictions in the form of an area under 
a receiver operating characteristic (ROC) curve (Table 1). The ROC curve is a measure of model accuracy which plots true positive rate vs. false positive rate, and the area under the ROC curve (AUC) provides a single measure of accuracy. The value of the AUC is between 0.5 and 1.0. A value of 0.8 for the AUC means that for $80 \%$ of the time, a random selection from the positive group will have a score greater than a random selection from the negative group (Fielding \& Bell 1997). In general, a model with an AUC value $>0.7$ is considered a good predictor. Model performance measures were calculated by tuning the model on $70 \%$ of data points and testing the model on $30 \%$ of data points. A confidence interval for the AUC was computed using stratified bootstrap replicates of the ROC value. Individual conditional expectation (ICE) plots were constructed using the ICEbox package in R (Goldstein et al. 2015). ICE plots are a version of partial dependence plots that graph both the average dependence of the predicted response (probability of presence) on 1 continuous predictor variable (BT, salinity) and the relationship between the predicted response and the predictor variable for individual observations. Moreover, the
ICEbox package allows for the exploration of interaction effects between predictor variables by determining the partial derivative curve of the partial dependence plots as well as color coding the ICE plots by a second predictor variable. For each species, ICE and derivative plots were calculated for salinity and BT. The salinity ICE plots and BT plots were color coded based on NAO and WNAO to visualize the interaction among these variables when predicting presence.

\subsection{Data availability}

The datasets analyzed during the current study are derived and available in the following repositories: Species presence data are available for download on the SEAMAP website (https://www2.dnr.sc.gov/ seamap/). Salinity and BT data are available for download on the HYCOM website (https://hycom. org/dataserver/gofs-3pt0/reanalysis). NAO data are available on the NOAA climate prediction center website (www.cpc.ncep.noaa.gov/products/precip/ CWlink/pna/nao.shtml). Bathymetric data can be

Table 1. Model performance measures for spring and fall random forest models for presence-absence models. Models were trained on $70 \%$ of the dataset and tested on $30 \%$. MAE: mean absolute error; MSE: mean squared error; RMSE: root mean squared error; ROC: receiver operating characteristic curve

\begin{tabular}{|c|c|c|c|c|c|c|c|c|c|}
\hline & MAE & MSE & RMSE & $\begin{array}{c}\text { Pearson's } \\
\text { r }\end{array}$ & $\begin{array}{l}\text { Kendall's } \\
\text { tau }\end{array}$ & $\begin{array}{l}\text { Spearman's } \\
\text { rho }\end{array}$ & $\begin{array}{c}\mathrm{R}^{2}(\mathrm{as} \\
\text { explained } \\
\text { variance/total } \\
\text { variance) }\end{array}$ & $\begin{array}{c}\mathrm{R}^{2} \\
\text { (as } 1-\mathrm{MSE} / \\
\text { total } \\
\text { variance) }\end{array}$ & $\begin{array}{l}\text { Area } \\
\text { under } \\
\text { ROC }\end{array}$ \\
\hline \multicolumn{10}{|c|}{ Atlantic croaker } \\
\hline Spring & 0.249 & 0.119 & 0.344 & 0.604 & 0.461 & 0.564 & 0.223 & 0.346 & 0.715 \\
\hline Fall & 0.328 & 0.149 & 0.387 & 0.588 & 0.475 & 0.582 & 0.151 & 0.306 & 0.642 \\
\hline \multicolumn{10}{|c|}{ Atlantic spadefish } \\
\hline Spring & 0.205 & 0.103 & 0.32 & 0.568 & 0.413 & 0.506 & 0.173 & 0.296 & 0.731 \\
\hline Fall & 0.378 & 0.17 & 0.413 & 0.593 & 0.498 & 0.61 & 0.165 & 0.318 & 0.635 \\
\hline \multicolumn{10}{|c|}{ Atlantic menhaden } \\
\hline Spring & 0.222 & 0.109 & 0.33 & 0.59 & 0.44 & 0.538 & 0.214 & 0.329 & 0.745 \\
\hline Fall & 0.149 & 0.08 & 0.283 & 0.541 & 0.373 & 0.457 & 0.106 & 0.237 & 0.592 \\
\hline \multicolumn{10}{|c|}{ Butterfish } \\
\hline Spring & 0.235 & 0.112 & 0.335 & 0.616 & 0.465 & 0.569 & 0.218 & 0.355 & 0.685 \\
\hline Fall & 0.367 & 0.165 & 0.406 & 0.594 & 0.495 & 0.606 & 0.152 & 0.312 & 0.651 \\
\hline \multicolumn{10}{|l|}{ Spot } \\
\hline Spring & 0.367 & 0.165 & 0.406 & 0.602 & 0.502 & 0.614 & 0.186 & 0.334 & 0.71 \\
\hline Fall & 0.322 & 0.149 & 0.385 & 0.57 & 0.464 & 0.568 & 0.129 & 0.28 & 0.595 \\
\hline \multicolumn{10}{|c|}{ Summer flounder } \\
\hline Spring & 0.239 & 0.116 & 0.341 & 0.534 & 0.404 & 0.495 & 0.116 & 0.246 & 0.574 \\
\hline Fall & 0.368 & 0.166 & 0.407 & 0.597 & 0.494 & 0.605 & 0.174 & 0.324 & 0.623 \\
\hline \multicolumn{10}{|c|}{ Weakfish } \\
\hline Spring & 0.391 & 0.179 & 0.423 & 0.555 & 0.457 & 0.56 & 0.137 & 0.274 & 0.612 \\
\hline Fall & 0.386 & 0.175 & 0.418 & 0.58 & 0.48 & 0.588 & 0.156 & 0.302 & 0.602 \\
\hline
\end{tabular}


downloaded from the GEBCO website (https://www. gebco.net/data_and_products/gridded_bathymetry_ data/gebco_30_second_grid). Substrate data are available for download from TNC for the northeastern United States (https://www.conservationgateway.org/ConservationByGeography/NorthAmerica/ UnitedStates/edc/reportsdata/marine/namera/namera/ Pages/Spatial-Data.aspx) and SAB (https://www. conservationgateway.org/ConservationByGeography/ NorthAmerica/UnitedStates/edc/reportsdata/marine/ sabma/sabma/Pages/Habitats-and-Species.aspx).

\section{RESULTS}

\subsection{Model performance}

The assessment of the model fits indicates that for the variables considered in the predictive model (BT, salinity, benthic habitat structure), the random forest approach captures between 23 and $35 \%$ of the variability in species presences (Table 1), with ROC curves ranging from 0.57 to 0.74 . None of the confidence intervals for the AUCs included 0.5 except for summer flounder in the spring, where after 2000 bootstrapped replicates, the $95 \%$ confidence interval for the AUC was between 0.4888 and 0.6599. We therefore recommend caution when interpreting the results from the spring summer flounder model.

\subsection{Model outcomes}

The results from the random forest models provide the probability of presence for each species in the spring and fall. Although the NAO may be associated with changes in BT and salinity (Visbeck et al. 2001, Nye et al. 2014), the heterogeneity of these variables determined by a correlation matrix suggests that the NAO and WNAO are capturing other environmental processes as well (Pearson's correlation coefficient ranged from -0.1 to 0.08 , see Fig. S2). Overall, salinity was the most important predictor variable for Atlantic croaker, Atlantic spadefish, spot, and weakfish in the fall and all species in the spring. BT was the most important predictor variable for summer flounder in the fall and butterfish in the spring. Either the NAO or WNAO was the most important variable for predicting presence of butterfish and Atlantic menhaden in the fall and the second-most important variable for predicting presence of spot, weakfish, and Atlantic croaker in the fall and summer flounder in the spring. Overall, the cyclical climate oscillations had more relative importance in the fall vs. spring (Fig. 3).

\subsection{ICE: partial dependence}

By visualizing the centered partial dependence plots for Atlantic croaker, Atlantic menhaden, butterfish, and spot in the fall, colored by NAO or WNAO phase, we see that this climate oscillation is likely influencing the relationships between salinity and presence, and between BT and presence (Fig. 4, Fig. S4). For Atlantic croaker, Atlantic menhaden, butterfish, and spot, cases with a negative WNAO or NAO value (blue) result in a negative relationship between BT and presence, and cases with a positive WNAO or NAO value (red) result in a positive relationship between BT and presence. For Atlantic croaker, Atlantic menhaden, butterfish, and spot, the cyclical oscillation (NAO or WNAO) has the highest or second-highest relative importance for predicting species presence. Thus, the responses of these species to increasing ocean temperatures and salinity may differ according to the NAO phase. In contrast, the presence of Atlantic spadefish, summer flounder, and weakfish in the fall are most influenced by BT and salinity. As a result, the centered partial dependence plots show little difference in trend depending on WNAO or NAO phase (Fig. 4), and the responses of these species to changing ocean temperatures and salinities will depend less on the phase of this cyclical oscillation. NAO, BT, and salinity ICE plot data for each species are shown in Fig. S4.

\section{DISCUSSION}

Our results demonstrate that the responses of several species to changing ocean BTs differ depending on the NAO phase. Thus, the predictability of species distribution shifts under changing ocean temperatures may depend on the relative importance of cyclical climate oscillations. Moreover, the direction of certain species shifts under a warming scenario may depend on the phase of the NAO. In the fall, the relative influence of BT on the presence of several species depends largely on the WNAO phase during that year. Thus, the direction that Atlantic croaker, Atlantic menhaden, butterfish, and spot will shift under warming may depend on the NAO phase. Consequently, the effect of increasing $\mathrm{CO}_{2}$ on the NAO is debated 


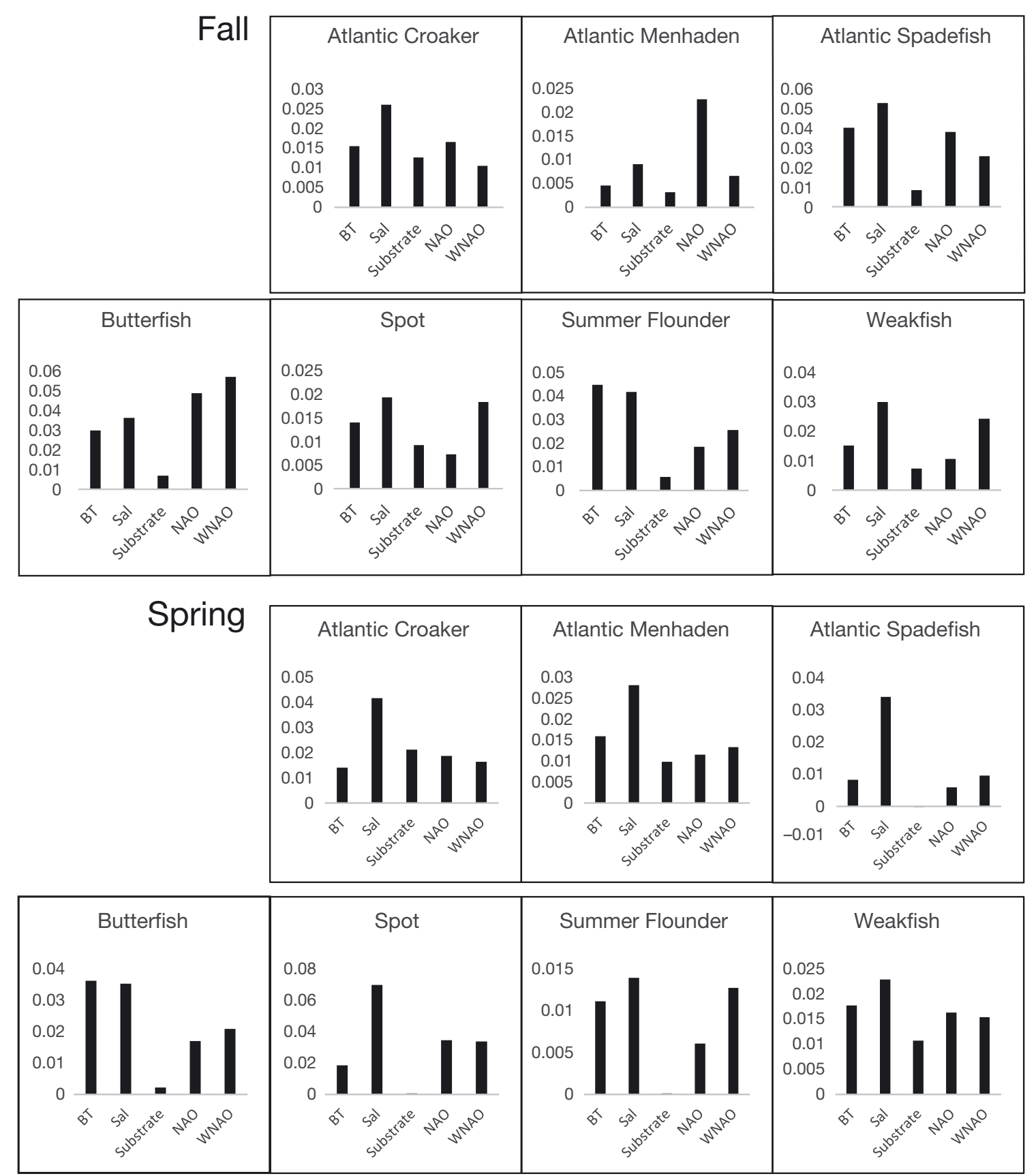

Fig. 3. Variable importance plots for random forest models on presence-absence data for the (a) fall and (b) spring. BT: bottom temperature; Sal: salinity; NAO: North Atlantic Oscillation; WNAO: winter North Atlantic Oscillation. Variable importance is calculated as the mean decrease in prediction accuracy after permuting the predictor variable (Xj) over all trees

(Rind et al. 2005, Gillett \& Fyfe 2013); thus, it is excluded from many climate studies predicting species shifts (Morley et al. 2018). Considering the expected continuous ocean warming (Kirtman et al. 2013) throughout the $S A B$, models predicting species distribution shifts should consider the interactive role of cyclical climate oscillations on species distributions.
The dependence of our model results on the phases of the NAO indicates that the physical variables considered here (BT, salinity) describe only a portion of the habitat associations for these species. Other processes associated with changes in the NAO, but not reflected in the local properties, appear to have important impacts on habitat distributions. Such properties might include phytoplankton or zooplankton 

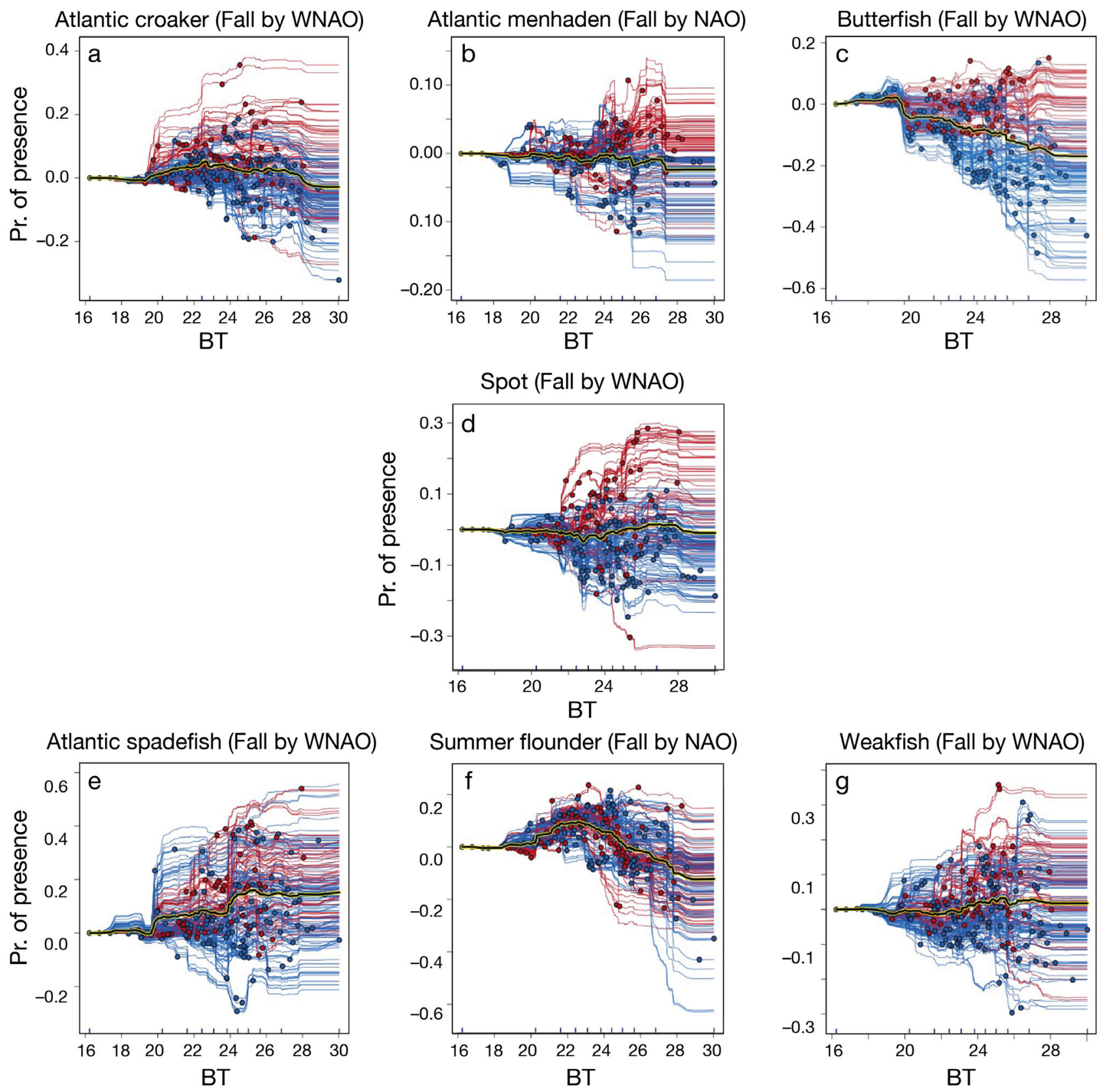

Fig. 4. Centered individual conditional expectation (ICE) partial dependence plots depicting bottom temperature (BT) influence on all species probability of presence colored by North Atlantic Oscillation (NAO) and winter North Atlantic Oscillation $($ WNAO) sign (blue = negative, red = positive) for the fall season. Points represent observations. The NAO or WNAO phase influences the effect of BT on probability of presence for (a) Atlantic croaker, (b) Atlantic menhaden, (c) butterfish, and (d) spot. No effect can be seen for (e) Atlantic spadefish, (f) summer flounder, and (g) weakfish. ICE partial dependence plots for both salinity and BT influence on presence colored by NAO and WNAO for all species can be found in Fig. S4 in the Supplement at www.int-res.com/articles/suppl/m614p159_supp.pdf

abundances, currents, wind patterns, or the frequency or intensity of storms and wind stress (Ottersen \& Stenseth 2005). The influence of the $\mathrm{NAO}$ on wind and water circulation patterns may influence larval advection or predator abundance, which may influence the relationship between BT and species distribution in different phases of the NAO. Studies have shown that the recruitment of Atlantic croaker is strongly influenced by the NAO via its influence on estuarine temperature and juvenile survival (Hare \& Able 2007). In conjunction with Hare \& Able (2007), who found that population bursts 
of Atlantic croaker occurred during relatively warm winters, our results suggest that during a positive, or warm, phase of the WNAO, BT is positively associated with the probability of presence of Atlantic croaker. This relationship is most likely due to the positive influence of the WNAO on Atlantic croaker recruitment. Additionally, nutrient supply and primary production differ between one phase of the NAO to the next (Oschlies 2001), which may affect the statistical relationship between BT and species presences by influencing prey abundance.

Butterfish and Atlantic menhaden were most influenced by the NAO, and the differing pattern of BT between NAO phases was evident for both of these species. The characteristics of both of these species may suggest that the NAO has a greater influence over pelagic distributions than local BTs. Both butterfish and Atlantic menhaden are pelagic schooling species, suggesting they can tolerate a wide range of temperatures and salinities (Rogers \& Van Den Avyle 1983a). Several studies have suggested that climatic variables that influence regional currents will affect menhaden larval transport and larval ingress (Warlen et al. 2002, Buchheister et al. 2016). The NAO has been associated with pelagic species distributions in Narragansett Bay, Rhode Island, where a positive NAO phase was associated with a switch from a primarily demersal-dominant community to a pelagicdominant community (Collie et al. 2008). In our study area, a positive NAO phase leads to warmer temperatures, increased precipitation, increased transport of the North Atlantic Current, and a strengthened gyre circulation (Ottersen \& Stenseth 2005). Perhaps increased transport leads to higher recruitment success and increased larval transport to estuaries. The NAO may influence the migrations of fish species, such as Atlantic menhaden and butterfish, through changes in environmental conditions that act as migratory cues. For example, American mackerel migrations depend on the seasonal movements of waters in a particular temperature range and mackerel will migrate at different times, depending on temperature fluctuations (Sette 1950).

The higher relative importance of the NAO and WNAO in the fall compared to the spring may reflect the within-year lagged response of species to the oceanographic shifts related to the NAO. While we ran each model with a $1 \mathrm{yr}$ lagged NAO, and the results for variable importance were the same, we suggest that there may be a within-year lagged response to the WNAO phase, and that the effects are most felt in the fall. Additionally, the higher importance in the fall could be reflective of seasonal migrations of each species. For example, Atlantic menhaden migrate south in the fall to spawn. Perhaps the influence of the NAO on the Labrador Shelf water is influencing the timing of menhaden's fall migration.

Atlantic spadefish, summer flounder, and weakfish were more influenced by salinity and BT (in terms of variable importance), and we did not show the differing influences of the NAO on their relationship with BT and salinity. Atlantic spadefish and summer flounder are demersal consumers that rely heavily on substrate for their habitats. Specifically, Atlantic spadefish are normally found around reef structures, while summer flounder typically burrow into the sandy substrate. Although habitat was not relatively important for the presence of any of the species studied, we believe that the nearshore extent of the original trawl samples might not have captured the variability in habitat across this region.

In addition to the influence of the NAO on the relationship between species presence and local BTs, our results also highlight that salinity was largely important for predicting the presence of the studied species, especially in the spring. Like many coastal marine species, the 7 studied species utilize estuaries for breeding and nursing, and they migrate between offshore and inshore environments during the spring or fall to spawn. Perhaps the high influence of salinity on presence in the spring is reflective of these migrations, as salinity tends to increase offshore. In general, the importance of salinity on these studied species presences must be considered when developing species distribution models that project distribution shifts under climate change, as many currently do not consider salinity (Marras et al. 2015, Kleisner et al. 2017).

Overall, the influence of the NAO phase on species responses to changing ocean temperatures presents an important question in climate change and fisheries research. We have shown that the relationship between butterfish, spot, Atlantic croaker, and Atlantic menhaden presence in the fall and increased BT differs depending on the phase of the NAO, and disentangling the underlying effects captured by the NAO that influence species relationships with BT warrants further research. While many studies that develop species distribution models (SDMs) use thermal preference as the main predictor of species occurrence, we strongly urge that SDMs focus on environmental covariates that influence biologically relevant processes. As was discussed by Fourcade et al. (2018), current evaluation metrics are unable to assess the biological significance of distribution models; thus, many models will include covariates that 
are not important ecologically. In conjunction with Fourcade et al., our results highlighting the influence of the NAO and salinity on several studied species presences suggest that SDMs for these species need to more rigorously select relevant predictors according to the species' ecology.

It is important to identify the limitations of the approaches used in this study. We used a dataset that was largely collected inshore at shallow depths $(<9 \mathrm{~m})$, and we recognize that the limited depth ranges do not represent the total distributions of the studied species. While datasets on the spatial distribution of catch of the studied species are unavailable, the known inshore migrations of the species as well as the lower cost of fishing nearshore suggests that the spatial extent of this survey will still prove useful for management plans. Additionally, although most of the ROC values in our models were around 0.7 , few exceeded that number. This could be because of the extent of the original dataset or the inability of environmental variables alone to predict species presences. Additionally, we chose to model the influence of environmental variables on species presences instead of species abundances. While the models using presence-absence data performed better than the models using abundance, we recognize that the environmental covariates we chose may have differing impacts on species abundances. We did, however, observe the same patterns on the differential effect of the NAO on species relationships with BT for the presence-absence models as well as the abundance models. Finally, research has indicated that biotic factors are extremely important for understanding species abundances and distributions (Davis et al. 1998), and these types of relationships, as well as population dynamics such as recruitment and population size, were not included in this study. As joint modeling techniques improve, a closer look at the joint distribution of these species may prove useful for management. Despite these limitations, we expect our results will be valuable for fisheries managers as they anticipate the likelihood of species distribution shifts in their management areas given the relative importance of habitat, $\mathrm{BT}$, and salinity as well as cyclical climate oscillations on commercially important species.

\section{CONCLUSIONS}

In general, the Mid-Atlantic and SAB are expected to experience increased ocean warming and salinity levels in the near future as a result of anthropogenic climate change. Consequently, species may shift distributions depending on their preferred temperature and salinity ranges and the importance of local BTs and salinities vs. other local variables influenced by climate oscillations on their distributions. For species that respond to local BTs and salinities, projected increases in BTs and salinities could linearly shift their distributions, while those that are influenced by climate oscillations would require SDMs that explore these relationships. Ultimately, future shifts in distributions will be dependent on the importance of BT and salinity relative to climate oscillations as well as local variables such as food security and circulation that affect population processes and distribution. In the end, we have shown that thermal preference will not be the only main driver of future shifts in distribution for all species.

This study demonstrates the importance of climate and fisheries research in the SAB and emphasizes a need for future research on the magnitude and direction of future species distributions and the underlying mechanisms of the NAO driving non-linear responses to changing ocean temperatures. Although modeling future species distributions requires a good understanding of species ecology, steps must be taken to predict future distribution shifts before they happen, giving management adequate time to respond.

Acknowledgements. We acknowledge members of the marine geospatial ecology lab for their technical expertise and programming help. We acknowledge the South Carolina Department of Natural Resources and Atlantic States Marine Fisheries Commission for collecting and publishing bottom water trawl survey data as well as contributors to TNC's North Atlantic Marine Ecological Assessment and SAB Marine Assessment for collecting and publishing bottom habitat data. We acknowledge the HYCOM consortium for providing BT and salinity data, and we thank the consortium for making their data freely available. S.M.R. and A.M.B. conceived of the presented idea. S.M.R. developed the methodology and performed the analysis. A.M.B. and R.R.R. verified the analytical methods. R.R.R. aided in the discussion of the NAO. All authors interpreted the results, and S.M.R. wrote the final manuscript. A.M.B., R.R.R., and P.N.H. revised the final manuscript. The authors declare no competing interests.

\section{LITERATURE CITED}

Adams CF, Miller TJ, Manderson JP, Richardson DE, Smith BE (2015) Butterfish 2014 stock assessment. US Dep Commer, Northeast Fish Sci Cent Ref Doc 15-06. www. nefsc.noaa.gov/publications/

Aller JY, Aller RC, Green MA (2002) Benthic faunal assemblages and carbon supply along the continental shelf/ 
shelf break-slope off Cape Hatteras, North Carolina. Deep Sea Res II 49:4599-4625

ASMFC (Atlantic States Marine Fisheries Commission) (1987) Fishery management plan for Atlantic croaker. Spec Sci Rep No. 48, Fish Manage Rep No. 10, ASMFC, Washington, DC

Brieman L (1984) Classification and regression trees. Wadsworth International Group, Belmont, CA

Briggs JC, Bowen BW (2012) A realignment of marine biogeographic provinces with particular reference to fish distributions. J Biogeogr 39:12-30

Buchheister A, Miller TJ, Houde ED, Secor DH, Latour RJ (2016) Spatial and temporal dynamics of Atlantic menhaden (Brevoortia tyrannus) recruitment in the Northwest Atlantic Ocean. ICES J Mar Sci 73:1147-1159

Byrd BL, Hohn AA, Lovewell GN, Altman KM and others (2014) Strandings as indicators of marine mammal biodiversity and human interactions off the coast of North Carolina. Fish Bull 112:1-23

Chassignet EP, Hurlburt HE, Smedstad OM, Halliwell GR and others (2007) The HYCOM (HYbrid Coordinate Ocean Model) data assimilative system. J Mar Syst 65: 60-83

Collie JS, Wood AD, Jeffries HP (2008) Long-term shifts in the species composition of a coastal fish community. Can J Fish Aquat Sci 65:1352-1365

* Cummings JA (2005) Operational multivariate ocean data assimilation. QJR Meteorol Soc 131:3583-3604

* Cutler DR, Edwards TC, Beard KH, Cutler A, Hess KT, Gibson J, Lawler JJ (2007) Random forests for classification in ecology. Ecology 88:2783-2792

* Davis AJ, Jenkinson LS, Lawton JH, Shorrocks B, Wood S (1998) Making mistakes when predicting shifts in species range in response to global warming. Nature 391: 783-786

Degenhardt F, Seifert S, Szymczak S (2017) Evaluation of variable selection methods for random forests and omics data sets. Brief Bioinform 217:bbx124

Drinkwater KF, Belgrano A, Borja A, Conversi A and others (2003) The response of marine ecosystems to climate variability associated with the North Atlantic Oscillation. In: Hurrell JW, Kushnir Y, Ottersen G, Visbeck M (eds) The North Atlantic Oscillation: climatic significance and environmental impact. Geophys Monogr 134, American Geophysical Union, Washington, DC, p 211-234

Fels J, Zobel R (1995) Landscape position and classifying landtype mapping for statewide DRASTIC mapping project. North Carolina State University Tech Rep VEL.95.1, North Carolina Department of Environment, Health, and Natural Resources, Division of Environmental Management, Raleigh, NC

Fielding AH, Bell JF (1997) A review of methods for the assessment of prediction errors in conservation presence/absence models. Environ Conserv 24:38-49

Fourcade Y, Besnard AG, Secondi J (2018) Paintings predict the distribution of species, or the challenge of selecting environmental predictors and evaluation statistics. Glob Ecol Biogeogr 27:245-256

Fox D, Teague W, Barron C, Carnes M, Lee C (2002) The modular ocean data assimilation system (MODAS). J Atmos Ocean Technol 19:240-252

GEBCO (2014) The GEBCO_2014 grid, version 20150318. www.gebco.net

* Gillett NP, Fyfe JC (2013) Annular mode changes in the CMIP5 simulations. Geophys Res Lett 40:1189-1193
Goldstein A, Kapelner A, Bleich J, Pitkin E (2015) Peeking inside the black box: visualizing statistical learning with plots of individual conditional expectation. J Comput Graph Stat 24:44-65

Greene JK, Anderson MG, Odell J, Steinberg N (eds) (2010) The Northwest Atlantic Marine Ecoregional Assessment: species, habitats and ecosystems. Phase One. The Nature Conservancy, Eastern US Division, Boston, MA

Hanna E, Cropper T (2017) North Atlantic Oscillation. Oxford Research Encyclopedia of Climate Science. http://oxfordre.com/climatescience/view/10.1093/acre fore/9780190228620.001.0001/acrefore-9780190228620e-22 (accessed 30 March 2019)

Hare JA, Able KW (2007) Mechanistic links between climate and fisheries along the east coast of the United States: explaining population outbursts of Atlantic croaker (Micropogonias undulatus). Fish Oceanogr 16:31-45

Hayse JW (1987) Feeding habits, age, growth, and reproduction of Atlantic spadefish Chaetodipterus faber (Pisces: Ephippidae) in South Carolina. Fish Bull 88: 67-83

Hothorn T, Bühlmann P, Dudoit S, Molinaro A, Van Der Laan MJ (2005) Survival ensembles. Biostatistics 7 : 355-373

Hurrell JW (1995) Decadal trends in the North Atlantic Oscillation: regional temperatures and precipitation. Science 269:676-679

Hurrell JW, Dickson RR (2004) Climate variability over the North Atlantic. In: Stenseth NC, Ottersen G, Hurrel JW, Belgrano A (eds)Marine ecosystems and climate variation: the North Atlantic. Oxford University Press, p 15-31

Hurrell JW, Kushnir Y, Ottersen G, Visbeck M (2013) An overview of the North Atlantic Oscillation. In: Hurrell JW, Kushnir Y, Ottersen G, Visbeck M (eds) The North Atlantic Oscillation: climatic significance and environmental impact. American Geophysical Union, Washington, DC, p 1-35

*Hurst TP, Conover DO (2002) Effects of temperature and salinity on survival of young-of-the-year Hudson River striped bass (Morone saxatilis): implications for optimal overwintering habitats. Can J Fish Aquat Sci 59:787-795

Kirtman B, Power SB, Adedoyin JA, Boer GJ and others (2013) Near-term climate change: projections and predictability. In: Stocker TF, Qin D, Plattner GK, Tignor M and others (eds) Climate change 2013: the physical science basis. Contribution of Working Group I to the Fifth Assessment Report of the Intergovernmental Panel on Climate Change. Cambridge University Press, Cambridge, p 953-1028

*Kleisner KM, Fogarty MJ, McGee S, Hare JA, Moret S, Perretti CT, Saba VS (2017) Marine species distribution shifts on the US Northeast continental shelf under continued ocean warming. Prog Oceanogr 153:24-36

Kursa MB (2014) Robustness of random forest-based gene selection methods. BMC Bioinformatics 15:8

*Levitus S, Antonov JI, Boyer TP, Baranova OK and others (2012) World ocean heat content and thermosteric sea level change (0-2000 m), 1955-2010. Geophys Res Lett 39:L10603

MAFMC (Mid-Atlantic Fishery Management Council) (2016) Ecosystem approach to fisheries management guidance document. MAFMC, Dover, DE. https://static1. squarespace.com/static/511cdc7fe4b00307a2628ac6/t/ 589a2b61d2b8575c64fe05ff/1486498674225/EAFM_ Guidance+Doc_2017-02-07.pdf 
Marras S, Cucco A, Antognarelli F, Azzurro E and others (2015) Predicting future thermal habitat suitability of competing native and invasive fish species: from metabolic scope to oceanographic modelling. Conserv Physiol 3:cou059

Mercer LP (1989) Species profiles: life histories and environmental requirements of coastal fishes and invertebrates (Mid-Atlantic) - weakfish. US Fish Wildl Surv Biol Rep 82(11.109), US Army Corps of Engineers TR EL-82-4

Miller KA, Munro GR (2004) Climate and cooperation: a new perspective on the management of shared fish stocks. Mar Resour Econ 19:367-393

Miller GC, Richards WJ (1980) Reef fish habitat, faunal assemblages, and factors determining distributions in the South Atlantic Bight. Proc Gulf Caribb Fish Inst 32: $114-130$

Moerlein KJ, Carothers C (2012) Total environment of change: impacts of climate change and social transitions on subsistence fisheries in northwest Alaska. Ecol Soc $17: 1$

Morley JW, Batt RD, Pinsky ML (2017) Marine assemblages respond rapidly to winter climate variability. Glob Chang Biol 23:2590-2601

Morley JW, Selden RL, Latour RJ, Frölicher TL, Seagraves RJ, Pinsky ML (2018) Projecting shifts in thermal habitat for 686 species on the North American continental shelf. PLOS ONE 13:e0196127

Myers RA, Drinkwater K (1989) The influence of Gulf Stream warm core rings on recruitment of fish in the northwest Atlantic. J Mar Res 47:635-656

NOAA (2015) Fisheries economics of the United States 2015. NOAA Tech Memo NMFS-F/SPO 170

* Nye JA, Link JS, Hare JA, Overholtz WJ (2009) Changing spatial distribution of fish stocks in relation to climate and population size on the Northeast United States continental shelf. Mar Ecol Prog Ser 393:111-129

Nye JA, Baker MR, Bell R, Kenny A and others (2014) Ecosystem effects of the Atlantic Multidecadal Oscillation. J Mar Syst 133:103-116

Oschlies A (2001) NAO induced long term changes in nutrient supply to the surface waters of the North Atlantic. Geophys Res Lett 28:1751-1754

Ottersen G, Planque B, Belgrano A, Post E, Reid PC, Stenseth NC (2001) Ecological effects of the North Atlantic Oscillation. Oecologia 128:1-14

Perry AL, Low PJ, Ellis JR, Reynolds JD (2005) Climate change and distribution shifts in marine fishes. Science 308:1912-1915

Phillips JM, Huish MT, Kerby JH, Moran DP (1989) Species profiles: life histories and environmental requirements of coastal fishes and invertebrates (Mid-Atlantic) - spot. US Fish Wildl Serv Biol Rep 82(11.98), US Army Corps of Engineers TR EL-82-4

Pinsky ML, Worm B, Fogarty MJ, Sarmiento JL, Levin SA (2013) Marine taxa track local climate velocities. Science 341:1239-1242

Pörtner HO, Schulte PM, Wood CM, Schiemer F (2010) Niche dimensions in fishes: an integrative view. Physiol Biochem Zool Ecol Evol Approach 83:808-826

R Development Core Team (2004) R: a language and environment for statistical computing. R Foundation for Statistical Computing, Vienna

Rind D, Perlwitz J, Lonergan P (2005) AO/NAO response to climate change. 1. Respective influences of stratospheric and tropospheric climate changes. J Geophys Res D Atmospheres 110:D12107

* Roberts JJ, Best BD, Dunn DC, Treml EA, Halpin PN (2010) Marine geospatial ecology tools: an integrated framework for ecological geoprocessing with ArcGIS, Python, R, MATLAB, and C++. Environ Model Softw 25: 1197-1207

Rogers SG, Van Den Avyle MJ (1983a) Species profiles: life histories and environmental requirements of coastal fishes and invertebrates (South Atlantic) - Atlantic menhaden. US Fish Wildl Surv Biol Rep FWS/OBS-82/11.11, US Army Corps of Engineers TR EL-82-4

Rogers SG, Van Den Avyle MJ (1983b) Species profiles. Life histories and environmental requirements of coastal fishes and invertebrates (South Atlantic) - summer flounder. US Fish Wildl Surv Biol Rep FWS/OBS-82/11.15, US Army Corps of Engineers TR EL-82-4

Santiago J (1998) The North Atlantic Oscillation and recruitment of temperate tunas. Col Vol Sci Pap ICCAT 48: 240-249

SEAMAP-SA Data Management Work Group (2014) Coastal survey; data acknowledgment and data caveats. http:// seamap.org/documents/Coastal Survey/SEAMAP CS Acknowledgment.pdf

SEAMAP-SA Data Management Work Group (2016) SEAMAP-SA online database. http://www.seamap.org/ datapage.html

Sette OE (1950) Biology of the Atlantic mackerel (Scomber scombrus) of North America. II. Migrations and habits. Fish Bull Fish Wildl Serv 51:251-358

Steve C, Gearhart J, Borggaard D, Sabo L, Hohn AA (2001) Characterization of North Carolina commercial fisheries with occasional interactions with marine mammals. NOAA Tech Memo NMFS-SEFSC-458

Stige LC, Ottersen G, Brander K, Chan KS, Stenseth NC (2006) Cod and climate: effect of the North Atlantic Oscillation on recruitment in the North Atlantic. Mar Ecol Prog Ser 325:227-241

Stommel HM (1958) The Gulf Stream: a physical and dynamical description. University of California Press, Berkeley, CA

Stram DL, Evans DCK (2009) Fishery management responses to climate change in the North Pacific. ICES J Mar Sci 66:1633-1639

Sumaila R, Cheung W, Lam V, Pauly D, Herrick S (2011) Climate change impacts on the biophysics and economics of world fisheries. Nat Clim Change 1:499-456

Talley L, McCartney M (1982) Distribution and circulation of Labrador Sea Water. J Phys Oceanogr 12:1189-1205

TNC (The Nature Conservancy) (2015) South Atlantic Bight marine assessment. Conservation gateway. https://www. conservationgateway.org/ConservationByGeography/North America/UnitedStates/edc/Documents/ED_SABMA_Sea floorDataDescriptions.pdf.

Visbeck MH, Hurrell JW, Polvani L, Cullen HM (2001) The North Atlantic Oscillation: past, present, and future. Proc Natl Acad Sci USA 98:12876-12877

Warlen SM, Able KW, Laban EH (2002) Recruitment of larval Atlantic menhaden to North Carolina and New Jersey estuaries: evidence for larval transport northward along the east coast of the United States. Fish Bull 100: $609-623$

Submitted: August 30, 2018; Accepted: February 10, 2019

Proofs received from author(s): March 30, 2019 